\title{
Efficiency increase of complex production and transport systems management
}

\author{
S. Kornilov ${ }^{1, *}, V$. Lukjanov $^{1}$, and $A$. Antonov ${ }^{1}$ \\ ${ }^{1}$ Mining Engineering and Transport Institute, Nosov Magnitogorsk State Technical University, Magnitogorsk, Russia
}

\begin{abstract}
This article deals with the problem of the reduced efficiency of management in complex production - transport systems due to the lack of co-ordination in the operation of industrial enterprises and transport carrying out their maintenance. The existing transport service schedules for auxiliary departments do not take into account possible changes in operating conditions, the probability of malfunctions and the amount of reserves, which leads to an increase in general production costs. To solve this problem, we propose to use the interval regulation of production and transport processes in all departments of the complex production and transport systems. Also, such regulation involves the determination of traffic service priority. This will allow passing on from the regulated control of production and transport processes to the situational one, adapted to specific conditions, and reducing losses from untimely transport servicing, which will lead to a stores reduction and efficiency increase of the enterprise circulating facilities use. Testing the effectiveness of interval regulation was performed on the system and dynamics simulation model of liquid iron transportation in the oxygen converter shop of the metallurgical enterprise. It was established that the use of interval regulation processes in iron production and its transportation will allow decreasing non-productive downtime by $21 \%$ and the amount of the liquid iron in anticipation of recasting in the oxygen converter shop - by $33 \%$. Economical effect of reducing the liquid iron downtime during transportation to the oxygen converter shop will be about 30 million rubles per year.
\end{abstract}

\section{Introduction}

Due to the market development in the country, there is a need to strengthen the links between suppliers, manufacturers and consumers. Transport plays a very important role in this process. Timely organization of transport maintenance allows coordinating the effective work of industrial enterprises in such a complex production and transportation system, as "supplier - manufacturer - consumer" (SMC). By efficiency we mean transport maintenance at certain times due to the SMC process constituents, while stocks of raw materials and finished products should be minimized to speed up the turnover of enterprises working capital.

\section{Urgency of the management efficiency problem in the SMC system}

One of the factors limiting the efficiency of the enterprises included in the SMC system is the lack of interaction coordination between enterprises, suppliers, companies-producers and enterprisesconsumers, as well as transport, carrying out their service and their intercommunication $[1,2,17]$. This factor is stipulated by the lack of centralized control system for all the above constituent parts of the SMC. Only during the interaction of the main and industrial railway transport enterprises in the metallurgical industry as a result of uncoordinated actions, on average, about 1.5 billion rubles a year for a single enterprise is lost by increasing inventory and slowing down its working capital turnover [3], and because of inconsistency in the transport and industrial production subsystems the costs are increased, on average, by $30 \%$ [4].

The complexity of the problems in the SMC management efficiency is caused by interdepartmental dissociation, the difference in the duration of the technological cycles and the individual operations of technological processes, the difference between the applied ways and operational methods of regulating the production and transport processes $[5-8,15]$.

\section{Problem and theory of the SMC management efficiency increase}

To improve the effectiveness of the management it is proposed to consider SMC as a single three-level system of interrelated elements with the appropriate levels of management. The first level (system-wide) implements the management of industrial enterprises belonging to the SMC system, taking into account their interaction and influence of the environment, by coordinating their production programs with main transportation plans. The second level (external) stipulates interaction of each industrial enterprise with the main transport connecting these businesses into a system. The third level (internal) implements

Corresponding author: kornilov_sn@mail.ru 
interaction of production subsystems with the industrial transport within each industrial company.

Taking into account such determination of the SMC, the management technique that allows to coordinate the technological cycles on all these levels has been developed. This technique is based on the agreed regulation of the production and transport operation duration. For example, let's consider the control at the internal level on the organization of production subsystems interaction at the metallurgical enterprises (the manufacturer in the SMC system) and its industrial vehicles.

As part of this method the integrated approach to the management of the production and transport processes should be applied, according to which all operations should be considered in connection with each other, i.e., the duration of some operations affects the duration of the others. For example, the turnover of the rolling stock in the transportation of liquid iron to the steelmaking department affects the interval between the pig iron tapping from the blast furnace. In accordance with this, the concept of interval regulation, which is defined as the maximum length of time for which the operation can be performed taking into account the fact that adjacent operation will be accomplished in compliance with the production and transport technology. Therefore, adjustment operations of intervals duration allow the modification of data values in a narrower range than these may vary in practice.

Thus, the interconnection of the related production units by a single technology involves a single mutually-coordinated duration of individual operations taking into consideration the requirements for each production subsystem and transport $[9,16]$. Let's consider the interaction of the blast furnace and the oxygen-converter shop (OCS), as well as industrial transport under the existing steel plant conditions (Table. 1). The tabulated data were obtained in 2015 by chronometric observations.

Table 1. Definition of Regulation Interval of the Main Production and Transport Operations in the Conveyance of Liquid Iron in the OCS.

\begin{tabular}{|c|c|c|c|c|c|}
\hline \multirow{2}{*}{$\begin{array}{c}\text { Name of } \\
\text { Operation }\end{array}$} & \multicolumn{2}{|c|}{$\begin{array}{c}\text { Duration of the } \\
\text { Operation, min }\end{array}$} & \multicolumn{2}{|c|}{$\begin{array}{c}\text { Regulation } \\
\text { Interval, min }\end{array}$} \\
\cline { 2 - 6 } & $\begin{array}{c}\text { Mini } \\
\text { mum }\end{array}$ & $\begin{array}{c}\text { Maxim } \\
\text { um }\end{array}$ & $\begin{array}{c}\text { meaning } \\
\text { over the } \\
\text { enterp } \\
\text { rise }\end{array}$ & $\begin{array}{c}\text { Mini } \\
\text { mum } \\
\text { meaning }\end{array}$ & $\begin{array}{c}\text { Maximum } \\
\text { meaning }\end{array}$ \\
\hline $\begin{array}{c}\text { The smelting } \\
\text { of pig iron in } \\
\text { blast } \\
\text { furnaces }\end{array}$ & 30 & 150 & 60 & 45 & 150 \\
\hline $\begin{array}{c}\text { Steel } \\
\text { production in } \\
\text { converters }\end{array}$ & 30 & 65 & 40 & 30 & $65^{*}$ \\
\hline $\begin{array}{c}\text { Transportatio } \\
\text { nof liquid } \\
\text { iron to the } \\
\text { OCS }\end{array}$ & 20 & 65 & 43 & 20 & 65 \\
\hline $\begin{array}{c}\text { Transportation } \\
\text { of hot-metal } \\
\text { mixer train }\end{array}$ & 20 & 60 & 40 & 20 & 60 \\
\hline
\end{tabular}

* the maximum value of the adjustment range is determined issuing from the minimization of production costs, however, in terms of actual production, in case of emergency, it can be increased to a greater value.

In determining the duration change of production and transport operations it is necessary to proceed from the fact that there are certain technological ways permitting to reduce or extend the periods of operations. For example, the intensity of the iron-production process can be changed by using the following methods:

a) changing the oxygen and the gas flow rate in the blast;

b) pressure changing under the blast furnace top;

c) changes in the content of iron and coke in the charge;

g) changes in the load mode of the blast furnace.

The above described methods of intensity regulation for producing pig iron can be used both separately and in total. As a result of the methods application the interval between the pig iron tapping from the blast furnace of the volume of $1500-2000 \mathrm{~m}^{3}$ may range from 30 to 150 minutes (Table 1.).

The duration change of operations is mainly due to the dispatching control. For example, the priority is given to a particular carriage at the expense of other conveyance delays. The change of movement speed and the execution of transport operations are rather strictly specified in the Rules for technical operation, in the Regulations for the movement of trains and shunting operations in rail transport, as well as in the local safety instructions.

The limits of regulation will mainly depend on the specific character of a particular company. Consequently, one of the most important tasks is the accurate determination of the values of intervals, which may change the duration of production and transport operations for each enterprise.

The currently applied schedules of production and transport operations which must ensure reliable operation of the enterprise subsystems contain average values of their duration, which does not always ensure the co-ordination of transport and main production subsystems. Furthermore, they do not consider the possibility of malfunction in production and transport subsystems, the probability of which is high enough in real conditions. In particular, the monitoring carried out for the transportation of liquid iron at the existing steel plant in the March - May 2015 led to the conclusion that the weighted average of the probabilities of failures occurrence is 0.51 . Thus, the currently used schedules do not reflect the actual production process and, consequently, lose their practical organizational role.

In this regard, it is proposed to replace rigidly fixed time expenditure for production and transport operations in the existing schedules for the time intervals to perform the necessary operations taking into consideration the relationships between them. Intervals introduction will allow the production and transport subsystems to change the rhythm of the work within the controlled intervals and to pass over from strictly normalized to adaptive (situational) management.

It is advisable to make similar calculations for technological cooperation of enterprises-suppliers, producers and consumers, as well as the main and industrial vehicles. In these cases, it is necessary to adjust the volume of traffic 
between the SMC companies with regard to their interaction with each other and the availability of the stocks of raw materials and finished products. Since the weighting rules for incoming and outgoing goods are strictly regulated, the traffic regulation will be carried out due to interval changes in its arrival and departure [10, 18, 19]. In general, this can be displayed using the following inequality.

1. Determination of the raw materials supply volume and export of finished products from the company-manufacturer can be fulfilled in the following way:

$$
\begin{aligned}
& \sum_{m=1}^{M} u_{c}(t) / t_{n c}-\sum_{i=1}^{I} V_{i c} / T_{i c} \leq U_{c}(t) \leq \\
& \leq u_{c}(t) / t_{n c}+V_{i c} / T_{i c} \\
& \sum_{n=1}^{N} u_{u g}(t)\left|t_{u g}-\sum_{k=1}^{K} V_{i u g}\right| N_{i u g} \leq U_{u g}(t) \leq \\
& \leq \sum_{n=1}^{N} u_{u g}(t)\left|t_{u g}+\sum_{k=1}^{K} V_{i u g}\right| N_{i u g}
\end{aligned}
$$

where $u_{c}(t)$ - the amount of raw materials processing during the technological cycle, $t$;

$t_{n c}$ - the duration of raw materials processing in a single technological unit, hour;

$V_{i c}$ - raw materials storage capacity, t;

$V_{i z n}$ - finished goods warehouse capacity, t;

$i$ - the number of raw materials warehouses;

$\kappa$ - the number of finished products warehouses;

$n-$ the number of units for the production of finished products;

$m$ - the number of units for processing of raw materials;

$T_{i c}$ - standard period of raw materials storage, hour;

$T_{i z n}$ - standard shelf life of the finished products, hour;

$U_{c}(t)$ - the volume of raw materials supply to the plant per unit of time, $\mathrm{t}$;

$t_{2 n}$ - the duration of the finished products output, hour;

$u_{2 n}(t)$ - the volume of finished products output for the production cycle, $t$;

$U_{2 n}(t)$ - the volume of the finished product removal from the enterprise per unit of time, $\mathrm{t}$.

2. Volume of finished products delivery to the enterpriseconsumer can be defined as follows:

$$
\begin{aligned}
\sum_{m=1}^{M} u_{n}(t) / t_{n n}- & \sum_{i=1}^{I} V_{i n} / T_{i n} \leq U_{n}(t) \leq \\
& \leq \sum_{m=1}^{M} u_{n}(t) / t_{n n}+\sum_{i=1}^{I} V_{i n} / T_{i n}
\end{aligned}
$$

where $u_{n}(t)$ - the volume of processed products for the production cycle, $t$;

$t_{n n}$ - the duration of the products processing in a single processing unit, hour;

$V_{\text {in }}$ - storage capacity for the arriving products, $\mathrm{t}$;

$i$ - the number of warehouses for the arriving products;

$m$ - the number of processing units for the arriving products processing;

$T_{i n}$ - standard shelf life of the arrived product, hour;

$U_{n}(t)$ - the volume of products delivery to the enterprise consumer per time unit, $\mathrm{t}$.

Inequalities (1), (2) and (3), (2) are considered together to determine the volumes and delivery intervals in the operational mode, taking into consideration the availability of raw materials and finished products at the enterprises.

Supply regulation throughout the whole way of the route is a very difficult task in practice, besides during the delivery time to the recipient company the need for the goods may be changed.

In this connection, it is proposed to carry out supply control at the adjacent highways to the company, which is designated as the area of attraction to the industrial enterprise (AAIE). AAIE dimensions should be selected in accordance with the time limits - 3-8 hours prior to the goods delivery to the enterprise, depending on the transport infrastructure. The lower control limit is determined by the necessity of accurate information pass about the goods arrival, and the top one by the average duration of a work shift in the main production unit. With an average speed of goods delivery up to $450 \mathrm{~km} /$ day, the AAIE border can be taken within a radius from 50 to 150 kilometers from the industrial enterprise.

When controlling the raw materials supply and removal of finished products within the AAIE the goods arrival and departure intervals obtained from (1), (2), (3) may have close values. In this case, the problem of determining priority of the arrival and departure of goods arises [11, 20, 21]. In this connection, it is proposed to adjust the intervals of arrival and departure separately for each kind of goods and its destination according to the urgency factor which is given by the formulas:

- for the goods arriving at the enterprise

$$
K_{\text {ср.пр }}=Q_{\text {тек.скл }} / Q_{\max }
$$

- for the finished product ready for departure

$$
K_{\text {ср.от }}=1-\left(Q_{\text {тек.скл }} / Q_{\text {max }}\right) \text {, }
$$

where $Q_{\text {тек.скл. }}-$ is the presence of the goods in stock at the moment, t;

$Q_{\text {max }}$ - is the maximum storage capacity for the given type of goods, $t$.

The values of the urgency coefficients may vary from zero to one. At the same time, the highest priority will correspond to a value of zero.

\section{Approval of Interval Control Procedures and Determination of Their Effectiveness}

To determine the effectiveness of the proposed interval regulation methods the system-dynamic simulation model of the liquid iron transportation from the blast furnace plant to the OCS of the existing steel plant has been constructed. The computer program AnyLogic was used as a simulation tool $[12,13,14]$. Indicators, in particular, the time loss during the liquid iron and transportation operations in the area of the blast furnace shop - OCS at the existing metallurgical enterprise, in March - May, 2015, were compared with the results of simulations when using the developed techniques of the interval control (Table 2.).

On the basis of a simulation modeling it was determined that the weighted average value of all the downtime was reduced by $21 \%$, and the one in the rolling stock with hot iron resulted by $33 \%$. The economic effect only from the reduction of liquid iron temperature losses by limiting the 
downtime during its transportation to the OCS will be about 30 million rubles per year.

Table 2. The Time Lost During the Liquid Iron Transportation in the OCS.

\begin{tabular}{|c|c|c|c|c|}
\hline \multirow{2}{*}{$\begin{array}{c}\text { Name of Inter- } \\
\text { operation } \\
\text { Downtime }\end{array}$} & \multicolumn{2}{|c|}{$\begin{array}{l}\text { Probability of } \\
\text { Downtime }\end{array}$} & \multicolumn{2}{|c|}{$\begin{array}{l}\text { Downtime } \\
\text { Average Value, } \\
\text { min }\end{array}$} \\
\hline & $\begin{array}{c}\text { In real } \\
\text { condi } \\
\text { tions }\end{array}$ & $\begin{array}{l}\text { On the } \\
\text { simu } \\
\text { lation } \\
\text { model }\end{array}$ & $\begin{array}{c}\text { In real } \\
\text { condi } \\
\text { tions }\end{array}$ & $\begin{array}{c}\text { On the } \\
\text { simulati } \\
\text { on } \\
\text { model }\end{array}$ \\
\hline $\begin{array}{l}\text { Waiting for free } \\
\text { rail ways while } \\
\text { driving the } \\
\text { locomotive under } \\
\text { the blast furnace }\end{array}$ & 0.18 & 0.15 & 8.0 & 6.5 \\
\hline $\begin{array}{l}\text { Waiting for } \\
\text { driving the } \\
\text { rolling stock } \\
\text { away from under } \\
\text { the blast furnaces } \\
\text { for technological } \\
\text { reasons }\end{array}$ & 0.74 & 0.68 & 12.2 & 10.8 \\
\hline $\begin{array}{l}\text { Waiting for free } \\
\text { rail ways when } \\
\text { driving the } \\
\text { rolling stock } \\
\text { away from under } \\
\text { the blast furnaces }\end{array}$ & 0.21 & 0.22 & 8.1 & 7.6 \\
\hline $\begin{array}{lr}\text { Waiting } & \text { for } \\
\text { orders for the } \\
\text { rolling stock } \\
\text { movement in } \\
\text { OCS }\end{array}$ & 0.14 & 0.11 & 5.8 & 5.2 \\
\hline $\begin{array}{l}\text { Feed delays to } \\
\text { the liquid iron } \\
\text { transfer } \\
\text { department }\end{array}$ & 0.68 & 0.42 & 24.8 & 10.6 \\
\hline $\begin{array}{l}\text { Delays in the } \\
\text { OCS and the } \\
\text { expectation of the } \\
\text { rolling stock } \\
\text { removal }\end{array}$ & 0.81 & 0.55 & 22.6 & 17.8 \\
\hline $\begin{array}{l}\text { Waiting for } \\
\text { orders for the } \\
\text { rolling stock } \\
\text { movement under } \\
\text { the blast furnaces }\end{array}$ & 0.13 & 0.12 & 5.2 & 5.0 \\
\hline
\end{tabular}

\section{Conclusion}

Thus, the suggested interval regulation in the system "Supplier - Transport Services - Manufacturer - Transport Services - Consumer" means the determination of interval control and urgent factors at every level of their interaction and reciprocal linking, which allows coordinating the work rhythms of production and transport facilities.

The application of this approach will enhance the management effectiveness at all levels of the SMC system, thereby, will reduce inventories by $20-30 \%$ (depending on the technology of work), will increase the use efficiency of the enterprises circulating assets.

\section{References}

1. A.N. Rakhmangulov, V.V. Baginova, N.A. Osintsev, The world of transport, 3, 108-113 (2010)

2. S.N. Kornilov, A.N. Rakhmangulov, A.D. Kolga, Vestnik of Nosov Magnitogorsk State Technical University, 1, 115-121 (2014)

3. A.N. Rakhmangulov, Methodological fundamentals of the railway and industrial transport technological systems functioning (Moscow, 2013)

4. O.V. Fridrihson, S.N. Kornilov, Modern problems of Russian transport complex, 2, 85-92 (2012).

5. A.N. Rakhmangulov, N.A. Osintsev, Vestnik of Nosov Magnitogorsk State Technical University, 1, 16-20 (2013)

6. A.N. Antonov, S.N. Kornilov, Moden problems of Russian transport complex, 1, 95-98 (2011)

7. A. Sładkowski, T. Pamuła, Studies in Systems Decision and Control, 32 (2016)

8. A.N. Rakhmangulov, O.A. Kopylova, Economy of region, 2, 254-263 (2014)

9. S.N. Kornilov, V.A. Lukjanov, Proc. Development of mineral deposits, 194-197 (2004)

10. S.N. Kornilov, V.A. Lukjanov, Proc. News of the advanced science, 30, 79-85 (2014)

11. V.A. Lukjanov, Innovative science, 7, 43-45 (2014).

12. A.N. Rakhmangulov, A.D. Kolga, N.A. Osintsev, I.N. Stolpovskikh, and A.V. Sladkowski, Transport Problems, 9, 3 125-132 (2014)

13. P.N. Michkurov, A.N. Rakhmangulov, Modern problems of Russian transport complex, 2, 143-152 (2012)

14. A. Rakhmangulov, A. Kolga, N. Osintsev, I. Stolpovskikh, A. Sladkowski, Transport Problems, 10, 2, 109-116(2015)

15. P.A. Kozlov, Transport of Russian Federation, 10, 3841 (2007)

16. S.N. Kornilov, K.M. Varzhina, Modern Problems of Russian Transport Complex, 5, 1, 12-16 (2015)

17. K.P. Shenfeld, E.A. Sotnikov, V.A. Ivnitsky, Vestnik of the Railway Research Institute, 3, 3-7 (2012)

18. A. Fugenschuh, H. Homfeld, A. Huck, A. Martin, Z. Yuan, Transportation Science, 42, 1-14

19. P. Pellegrini, G. Marli`ere, J. Rodriguez, G. Marliere, Transportation Research Part B, 59, 58-80

20. T.G. Crainic, G. Laporte, European Journal of Operational Research, 3, 409-438 (1997)

21. A.F. Borodin, E.A. Sotnikov, Railway Transport, 3, 819 (2011) 